\title{
TEACHING PREGNANCY INDUCED HYPERTENSION TO MEDICAL STUDENTS- AN INTEGRATED APPROACH
}

\author{
Sudakshina Chakrabarti ${ }^{1}$
}

${ }_{1}^{1}$ Assistant Professor, Department of Anatomy, Saveetha Medical College, Kuthambakkam, Tamilnadu, India.

\section{ABSTRACT}

\section{BACKGROUND}

Medical education is an evolving scientific field with new modifications and changes in teaching style added continuously for the betterment of medical students. Vertically integrated teaching of medical subjects is gaining momentum in the field of medical education in recent times. Revising the basic concepts of a particular common condition regularly seen in clinics with regular casebased teaching of clinical final year subjects leads to better understanding and learning among the medical students. Vertical integration makes the medical students ready with better preparedness to face real patients in future and thus works for their transition to a quality Indian medical graduate.

The objectives of the study were- 1 . To evaluate the effectiveness of vertically integrated teaching by taking classes regarding 'pregnancy induced hypertension' along with basic concepts to final year MBBS students of 2014-15 batch by pre and post-test analysis. 2. To obtain valuable feedback from the medical students and analyse the feedback for future use.

\section{MATERIALS AND METHODS}

This pre- and post-test study conducted in Saveetha Medical College, Chennai, India on final year MBBS students for teaching 'Pregnancy Induced Hypertension' as a single day workshop with clinical case-based approach involving basic science experts. In six stations, twelve cases were discussed by a galaxy of experts from clinical and basic science departments. Pre-test and post-test results were analysed. Feedback was taken from the students at the end of the day-long session and it was analysed.

\section{RESULTS}

Analysis of pre- and post-tests by questionnaires showed an increase in the scores of the students. This was plotted in a box plot. The feedback given by the student's too preferred vertically integrated problem-based learning as a better method rather than didactic lectures and bedside teaching only.

\section{CONCLUSION}

This study shows a single one-day program of vertically integrated teaching of a common clinical condition broke the monotony of the curriculum and lead to an enjoyable learning experience to the final year medical students. Students expressed their preference towards more sessions of vertical integration programs in future through their valuable feedback. The efforts of all facilitators were acknowledged by the students and their improvement in scores in post-test motivated them in participating in these sessions in future. The application of their basic science knowledge into clinical problem-based approach of learning proved extremely useful in this study.

\section{KEY WORDS}

Vertical Integration, Teaching, Medical Education.

HOW TO CITE THIS ARTICLE: Chakrabarti S. Teaching pregnancy induced hypertension to medical students- an integrated approach. J. Evolution Med. Dent. Sci. 2019;8(05):285-288, DOI: 10.14260/jemds/2019/63

\section{BACKGROUND}

Vertical integration is defined as the integration between the clinical and basic science subjects of the medical curriculum. In present day, it should occur throughout the medical curriculum with the basic medical and clinical sciences beginning together in the early years of the curriculum and continuing until the later years. Though the traditional way of teaching in medical curriculum puts more emphasis on the basic medical science subjects in the earlier years and on clinical science subjects in the later years a coordinated

'Financial or Other Competing Interest': None.

Submission 22-11-2018, Peer Review 22-01-2019,

Acceptance 28-01-2019, Published 04-02-2019.

Corresponding Author:

Dr. Sudakshina Chakrabarti,

Assistant Professor, Department of Anatomy,

Saveetha Medical College,

Kuthambakkam, Tamilnadu, India.

E-mail: sudhianat@gmail.com

DOI: $10.14260 /$ jemds/2019/63 approach is the need of the hour and can result in better understanding. ${ }^{1}$ Medical education is reforming itself rapidly throughout the globe. The concept of horizontal and vertical integration which was recently introduced in medical education is now being rampantly practiced in most countries worldwide. There is a constant attempt in improving the awareness and adopting better practices in teaching and learning in medical education through faculty development programs worldwide.2,3,4 Vertical integration of basic science subjects and clinical subjects has been found to stimulate deeper and profound rather than superficial concept-based learning, and thus results in complete understanding of biomedical principles. The knowledge of basic science subjects especially Anatomy, Physiology and Biochemistry which are taught in first year MBBS are tough to retain and it becomes very difficult for medical students to apply the knowledge for clinical practices during their final years of medical education. Thus, the need of the hour is a system of vertical integration of knowledge attained by medical students during their first year MBBS with the clinical practices commonly taught during their final years.., 6 
Medical school curricula have been revised so that they represent vertically integrated programs from the first year of the training. A fully vertically integrated undergraduate medical curriculum can be defined by the following four features-

a. Provision of early clinical experience.

b. Integration of biomedical sciences and clinical cases.

c. Progressive increase of clinical responsibility longitudinally and extended internships in the final year of medical school.7-11

d. The aim of vertical integration is to promote the transition of a medical graduate from medical school to clinical practice and eventually postgraduate training. In this study our aim was to design and implement a vertically integrated module for teaching obstetrics (Pregnancy induced hypertension) in a modified way to the final year MBBS students at Saveetha Medical College and Hospital Chennai. This was an effort of interactive teaching and learning experience to eliminate the sharp boundaries between basic and clinical sciences in undergraduate teaching of MBBS students.

\section{Aims and Objectives}

To study the effectiveness of vertically integrated teaching of pregnancy induced hypertension along with basic concepts to final year MBBS students of 2013-14 batch by pre and posttest analysis of the performance of the students.

To obtain feedback from these medical students at the end of the program and analyse the feedback of this vertically integrated teaching and learning experience.

\section{MATERIALS AND METHODS}

The study was conducted as a one-day teaching-learning program for final year students (120) 2013-14 batch of Saveetha Medical College, Chennai this is a pre-test and posttest study thus a quasi-experimental study combined with a feedback study. The idea was to involve the students to the fullest and not to conduct this program for the students. The preparation was taken in a stepwise manner.

\section{Step I/Preparation of Learning Module- Keep it Simple}

A team of experts from the departments of anatomy, biochemistry, physiology, pathology, pharmacology, radiology, neonatal medicine, general medicine, obstetrics and anaesthesia was briefed on the teaching principle of vertical integration.

Students were given the learning module in PDF format in web forum a fortnight before the actual clinical problems were given to them. The medical students were divided in groups to facilitate participatory group-based activity. The final module was discussed in 6 batches of 20 students together in the presence of a teaching faculty. On the day of the program students were asked to answer pre-test questionnaire.

\section{Step 2/Case Based Discussion}

Twelve case scenarios of pregnancy-induced hypertension were given for problem solving to the medical students. According to the barrow taxonomy of PBL methods the case scenarios were "full problem simulation" and "Student directed learning". Students were divided into six groups. Each group of twenty students were given two cases for problem-based learning. A galaxy of experts from each department sat with students forming six stations. Table 1.

\section{Step 3/Plenary Session}

Discussion- The cases were discussed with the experts of the disciplines integrated.

\section{Step 4/Mind Mapping}

The medical students of each group charted the concepts gained collectively. This was a participatory activity as the students of each group took one chart paper to outline their ideas. They signed their names below each chart. They were able to solve the clinical cases with the basic science preclinical knowledge with only a very little help from clinicians. Post-test was conducted. Feedback from the students were taken regarding the efficacy and usefulness of the program. The questions in the feedback form was adapted from pretested questionnaire used for another study for physiology module. ${ }^{12}$

\section{Statistical Analysis}

Statistical analysis was done using the software SPSS version 21. Mean of Pre-test scores and Post-test scores for all the parameters were compared using Paired samples t-test. Cognitive gain was calculated as Post-test score minus Pretest score. For all statistical evaluations, probability of value $<0.05$ was considered significant.

\section{RESULTS}

Analysis of pre and post-tests by questionnaires showed an increase in the scores of the students. This was plotted in a box plot and significant difference is noted as in table 4 . The feedback given by the student's too preferred vertically integrated problem-based learning as a better method rather than didactic lectures and bedside teaching only.

\begin{tabular}{|c|}
\hline 1. Epilepsy with pregnancy. \\
\hline $\begin{array}{l}\text { 2. Pregnancy with oliguria with normal Placental growth } \\
\text { factor. }\end{array}$ \\
\hline 3. Severe preeclampsia with HELLP syndrome. \\
\hline $\begin{array}{l}\text { 4. Gestational hypertension progressing to severe } \\
\text { preeclampsia. }\end{array}$ \\
\hline 5. Eclampsia at term \\
\hline 6. Severe preeclampsia with abruptio placentae in labour. \\
\hline $\begin{array}{l}\text { 7. Severe preeclampsia with IUGR with prematurity with } \\
\text { brain sparing effect. }\end{array}$ \\
\hline 8. Post-partum eclampsia. \\
\hline $\begin{array}{l}\text { 9. Pregnancy at } 24 \text { weeks with uterine artery abnormal } \\
\text { pulsatility index. }\end{array}$ \\
\hline $\begin{array}{l}\text { 10. Severe preeclampsia at term with abnormal } \\
\text { cerebroplacental ratio. }\end{array}$ \\
\hline $\begin{array}{l}\text { 11. Epidural anaesthesia in severe preeclampsia with IUGR } \\
\text { with reversed umbilical artery diastolic flow. }\end{array}$ \\
\hline 12. General anaesthesia in eclampsia. \\
\hline Table 1. Cases Given to Stı \\
\hline
\end{tabular}




\begin{tabular}{|c|c|c|c|}
\hline Questions & Agree & Disagree & Uncertain \\
\hline $\begin{array}{c}\text { Teaching pregnancy induced } \\
\text { hypertension concepts in } \\
\text { integration with clinical } \\
\text { scenarios is a better approach } \\
\text { than the traditional teaching? }\end{array}$ & 93 & 4 & 3 \\
\hline $\begin{array}{c}\text { Integrated approach makes } \\
\text { learning and understanding } \\
\text { easy. }\end{array}$ & 89 & 6 & 5 \\
\hline $\begin{array}{c}\text { This mode of teaching and } \\
\text { assessment motivated your } \\
\text { critical thinking? }\end{array}$ & 81 & 4 & 15 \\
\hline $\begin{array}{c}\text { This mode of teaching would } \\
\text { be helpful to you in the future } \\
\text { years for better } \\
\text { understanding of the clinical } \\
\text { concepts? }\end{array}$ & 86 & 4 & 10 \\
\hline $\begin{array}{c}\text { Assessment of knowledge by } \\
\text { the use of clinical scenario- } \\
\text { based questions is a better } \\
\text { way of judging the knowledge } \\
\text { of the students? }\end{array}$ & 90 & 4 & 6 \\
\hline \begin{tabular}{c} 
Table 2 \\
\hline
\end{tabular} & & \\
\hline
\end{tabular}

\begin{tabular}{|c|c|c|}
\hline Questions & Agree & $\begin{array}{c}\text { Disagree or } \\
\text { Uncertain }\end{array}$ \\
\hline $\begin{array}{c}\text { Facilitators interacted with the } \\
\text { students }\end{array}$ & 87 & 13 \\
\hline $\begin{array}{c}\text { Facilitators gave clear explanations } \\
\text { and relevant information }\end{array}$ & 88 & 12 \\
\hline I find the module interesting & 90 & 10 \\
\hline Facilitator encouraged participation & 92 & 8 \\
\hline $\begin{array}{c}\text { Facilitator encouraged critical } \\
\text { thinking }\end{array}$ & 85 & 15 \\
\hline $\begin{array}{c}\text { This integrated mode of teaching and } \\
\text { assessment be continued in future? } \\
\text { Module was well organized }\end{array}$ & 91 & 9 \\
\hline \multicolumn{2}{|c|}{ Table 3 } \\
\hline
\end{tabular}

\begin{tabular}{|c|c|c|c|c|}
\hline Pair & Mean & N & $\begin{array}{c}\text { Std. } \\
\text { Deviation }\end{array}$ & $\begin{array}{c}\text { Std. Error } \\
\text { of Mean }\end{array}$ \\
\hline Pre-test & 24.29 & 120 & 5.44 & 0.50 \\
\hline Post-test & 34.51 & 120 & 6.13 & 0.56 \\
\hline Table 4. Paired Sample Statistics of Pre and Post test \\
results \\
\hline \multicolumn{5}{|c|}{$\mathrm{p}>0.05$} \\
\hline
\end{tabular}

\section{Pre-Test and Post-Test}

A set of twenty multiple response multiple choice questions were used for pre-plenary assessment. The same questionnaire was given to students after the case based plenary session was over. The scores obtained were plotted using box charts for pre-test and post-test. The median, the 25 th percentile, the 75 th percentile and extreme values in pre-test and post-test group were plotted using sigma plot. An improvement of scores was observed in post-test compared to pre-test.

\section{Feedback Analysis}

$83 \%$ of the students agreed that teaching basic concepts about pregnancy induced hypertension in integration with clinical case scenarios is a better approach than traditional teaching. $95 \%$ of the students responded that integrated approach makes learning and understanding easy. 85\% of the students agreed that this mode of teaching and assessment motivated their critical thinking. $91 \%$ of the students hoped that this mode of teaching would be helpful to them in future clinical years Table 2 .

The student's responses about the module organization and delivery are summarized in Table 3.91\% of the students agreed that the Module was well organized and $90 \%$ of the students found this module interesting.

\section{DISCUSSION}

The traditional method of teaching medicine implies that students should first learn basic and biomedical science subjects and then move to clinical science subjects following years; however, this is not how patients are presented. This approach is subjected to criticism as the medical students will not be able to appreciate the relevance of basic and biomedical sciences applied to clinical practice, and it is preferable to encourage students to think as doctors from the day they enter medical school.13 Participatory learning activities keep students alert and interested. A thorough knowledge of basic sciences is essential for patient dealing. The clinical skills need to be interweaved in the training matrix through a student centric approach. The medical students voted peer instruction and group discussion among themselves as the best learning method. Many students are displaced from family and friends for the first time in medical schools. Students fared better in post-test and they felt for complete understanding of the subject integrated teaching of basic concepts with clinical applicative learning is extremely useful. Similar results have been quoted by Brynhildsen J et al, feedback from their students and faculty showed that vertically integrated teaching methodology is better than the traditional teaching. 14 In another study the students perceived that integrated teaching improves their performance in clinics when they face the clinical cases. 15 This is in accordance with our results, $91 \%$ of our students think that integrated mode of teaching will be helpful to them in the future years for better understanding of the clinical concepts.

\section{CONCLUSION}

This study shows a single one-day program of vertically integrated teaching of a common clinical condition broke the monotony of the curriculum and lead to an enjoyable learning experience to the final year medical students. Students expressed their preference towards more sessions of vertical integration programs in future through their valuable feedback. The efforts of all facilitators were acknowledged by the students and their improvement in scores in post-test motivated them in participating in these sessions in future. The application of their basic science knowledge into clinical problem-based approach of learning proved extremely useful in this study.

\section{REFERENCES}

[1] Brynhildsen J, Dahle LO, Fallsberg BM, et al. Attitudes among students and teachers on vertical integration between clinical medicine and basic science within a problem-based undergraduate medical curriculum. Med Teach 2002;24(3):286-8. 
[2] Anderson MB. A guide to the 130 reports in this snapshot supplement to Academic Medicine. Acad Med 2000;75(Suppl 9):S10-S14.

[3] Jones R, Higgs R, De Angelis C, et al. Changing face of medical curricula. Lancet 2001;357(9257):699-703.

[4] Swanson AG, Anderson MB. Educating medical students. Assessing change in medical education--the road to implementation. Acad Med 1993;68(Suppl 6):S1-46.

[5] Dahle LO, Brynhildsen J, Fallsberg FM, et al. Pros and cons of vertical integration between clinical medicine and basic science within a problem-based undergraduate medical curriculum: examples and experiences from Linköping, Sweden. Med Teach 2002;24(3):280-5.

[6] Singh A, Katyal R, Chandra S, et al. Study of impact of vertical integration in medical education in a medical college of India. International Journal of Community Medicine and Public Health 2017;4(9):3328-33.

[7] Wijnen-Meijer M, ten Cate 0, Van der Schaaf M, et al. Graduates from vertically integrated curricula. Clin Teach 2013;10(3):155-9.

[8] Harden RM, Sowden S, Dunn WR. Educational strategies in curriculum development: the SPICES model. Med Educ 1984;18(4):284-97.
[9] Schmidt HG, Machiels-Bongaerts M, Hermans H, et al. The development of a diagnostic competence: comparison of a problem-based, an integrated and a conventional medical curriculum. Acad Med 1996;71(6):658-64.

[10] Vidic B, Weilauf HM. Horizontal and vertical integration of academic disciplines in the medical school curriculum. Clin Anat 2002;15(3):233-5.

[11] Cate TO. Medical education in the Netherlands. Med Teach 2007;29(8):752-7.

[12] Rafique N. Importance of vertical integration in teaching and assessment of physiological concepts. Journal of Taibah University Medical Sciences 2014;9(4):282-8.

[13] Harden RM. Approaches to curriculum planning. Med Educ 1986;20(5):458-66.

[14] Miller GE. The assessment of clinical skills/competence/performance. Acad Med 1990;65(Suppl 9):S63-7.

[15] Kalpana KM, Vijaya V, Seema R, et al. Students perception in teaching in an integrated Undergraduate Medical Curriculum. Journal of Clinical and Diagnostic Research 2011;5:1258-9. 